\title{
MATERIAL COMPETENCE OF THE NATIONAL DIRECTORATE FOR INVESTIGATING ORGANIZED CRIME AND TERRORISM
}

\author{
B. Micu
}

\section{Bogdan Micu}

Law Faculty, Criminal Sciences Department

"Nicolae Titulescu" University, Bucharest, Romania, Calea Văcăreşti, no. 185

e-mail: Bogdan.micu@mnpartners.ro

\begin{abstract}
:
In Romania, nowadays, there is a general effort to prevent, but also to combat the most important categories of crimes, those which have the aptitude to affect public order and social peace. It is about violent crimes relied to organized criminality and to organized crime itself. In order to succeed in this effort, there were created specialized judicial authorities, with competences in prosecuting these cases, as National Directorate for Investigating Organized Crime and Terrorism or National Anticorruption Directorate. Being concerned not to omit some crimes in these special competences, sometimes, can be observed positive conflict of competences between the special judicial authorities. This study observes some particular situation and indicates the adequate solution for each of them.
\end{abstract}

Key words: National Directorate for Investigating Organized Crime and Terrorism; National Anticorruption Directorate; prosecution competence; positive conflict of competence.

\section{Introduction}

In accordance with provisions of art. 1, para. (1) of Law no. 508/2004 ${ }^{1}$, the Directorate for Investigating Organized Crime and Terrorism (hereinafter referred to as DIOCT), operates as a structure specialized in countering organized crime and terrorism, within the Public Prosecution Office of the High Court of Cassation and Justice.

This structure's authority is to perform criminal prosecution in particular cases. Crimes that determine this authority are indicated under art. 12 of Law no. 508/2004 and the indicated text specifies that the authority is "regardless of the person's position/quality", meaning an authority determined only by the nature of the crime ${ }^{2}$. Please find below an analysis of the crimes specified by law.

\section{The material competence of DIOCT}

a) Crimes those are included in the scope of an organized criminal group

\footnotetext{
${ }^{1}$ Law on the establishment, organisation and operation within the Public Ministry of the Directorate for Investigating Organised Crime and Terrorism, published in the Official Journal of Romania, Part I, no. 1089 dated 23 November 2004, as amended and supplemented.

${ }^{2}$ I. Neagu, M. Damaschin, Tratat de procedură penală, Partea generală, Universul Juridic PH, Bucureşti, 2014, p. 338.
} 


\section{MATERIAL COMPETENCE OF THE NATIONAL DIRECTORATE FOR INVESTIGATING \\ ORGANIZED CRIME AND TERRORISM}

According to the meaning of article 367, para. (6) of the Criminal Code, an organized criminal group means a structured group consisting of three or more persons, established for a particular period of time to act in a coordinated manner in order to commit one or more crimes. Therefore, it mentions one of the forms of mandatory plurality of perpetrators, specifically established plurality. Under this circumstance, the lawmaker chose to incriminate the simple establishment of a group in order to commit crimes ${ }^{3}$.

DIOCT's authority is involved in particular crimes, in the extent they are found in the program of such an organized criminal group. The lawmaker chose to specify the crimes expressly:

- the crimes of murder (art. 188 Criminal Code), first-degree murder (art. 189 Criminal Code), unlawful deprivation of freedom (art. 205 Criminal Code), blackmail (art. 207 Criminal Code), slavery (art. 209 Criminal Code), subjection to forced or mandatory labour (art. 212 Criminal Code), procurement (art. 213 Criminal Code), exploitation of begging (art. 214 Criminal Code), use of an underage person for begging purposes (art. 215 Criminal Code), use of services of an exploited person (art. 217 Criminal Code), computer fraud (art. 249 Criminal Code), fraudulent performance of financial operations (art. 250 Criminal Code), acceptance of financial operations performed fraudulently (art. 251 Criminal Code), property damage (art. 263 Criminal Code), first-degree criminal damage (art. 264 Criminal Code), currency forgery (art. 310 Criminal Code), forgery of credit instruments or payment instruments (art. 311 Criminal Code), circulation of forged currency or forged credit or payment instruments (art. 313 Criminal Code, with reference to forged instruments stipulated under article 310 and article 311 Criminal Code), holding of instruments in order to forge securities (art. 314 Criminal Code), fraudulent issue of currency (art. 315 Criminal Code), forgery of foreign securities if the forged foreign securities are forged coins or credit or payment instruments (art. 316, with reference to art. 310 and art. 311), computer fraud (art. 325 Criminal Code), infringement of the arms and ammunition conditions (art. 342 Criminal Code), unlawful use of weapons (art. 343 Criminal Code), forgery, deletion or modification of marking on lethal weapons (art. 344 Criminal Code), infringement of conditions on nuclear materials or other radioactive materials (art. 345 Criminal Code), infringement of conditions on explosive materials (art. 346 Criminal Code), criminal usury (art. 351 Criminal Code), trafficking toxic products or substances (art. 359 Criminal Code), illegal access to a computer system (art. 360 Criminal Code), illegal interception of a transmission of computer data (art. 361 Criminal Code), alteration of integrity of computer data (art. 362 Criminal Code), disruption of operation of computer systems (art. 363 Criminal Code), unauthorized transfer of computer data (art. 364 Criminal Code), illegal operations with computer devices or programs (art. 365 Criminal Code);

- the crime of theft (art. 228 Criminal Code), aggravated theft (art. 229 Criminal Code), robbery (art. 233 Criminal Code), aggravated robbery (art. 234 Criminal Code), piracy (art. 235 Criminal Code), robbery or piracy followed by the death of the victim (art. 237 Criminal Code), abuse of trust by defrauding the creditors (art. 239 Criminal Code), simple bankruptcy (art. 240 Criminal Code), fraudulent bankruptcy (art. 241 Criminal Code), fraudulent

\footnotetext{
${ }^{3}$ M. Gorunescu, I.A. Barbu, M. Rotaru, Drept penal, Partea general, Universul Juridic PH, București, 2014, p. 196.
} 


\section{B. $\mathrm{Micu}$}

management (art. 242 Criminal Code), fraud (art. 244 Criminal Code), insurance fraud (art. 245 Criminal Code), embezzlement of public tenders (art. 246 Criminal Code), patrimonial exploitation of vulnerable persons (art. 247 Criminal Code), misappropriation (art. 295 Criminal Code, art. 308-309 Criminal Code), embezzlement of funds (art. 307 Criminal Code, including the scenario under art. 309 Criminal Code, but only if the case, regardless of the number of concurring crimes, the material damage incurred exceeds the Romanian currency equivalent of EUR 500,000.00;

- the crime stipulated under art. 5 of Law no. 11/1991 on the countering of disloyal competition ${ }^{4}$. In legal contextual definition, art. 2, para. (1) of the same regulation provides a generic definition of the acts that represent disloyal competition as being those "commercial practices of the enterprise that come against fair practices and the general principle of good faith and which generate or may generate damages to any participants on the market". The definition of disloyal competition is found in article 5, the behavior patterns representing the material element including: a) the use of a company, logo or packing material likely to generate confusion with those used legitimately by a different company; b) the use in commercial purposes results of experiments or of other confidential information related thereto, transmitted to competent authorities in order to obtain authorizations to market pharmaceutical products or chemical products destined for agriculture, which include new chemical compounds; c) disclosure, acquisition or use of trade secrets by third parties, as a result of industrial espionage, if this affects the interests or activity of a legal entity; d) disclosure or use of commercial secrets by persons authorized by the legitimate holders of such commercial secrets to represent them in front of public authorities or public institutions, if this affects the interests or activity of a legal entity; e) the use by a public servant in the meaning of article 175, para. (1) of the Criminal Code ${ }^{5}$, of commercial secrets of which they become aware during the exercise of job attributions, if this affects the interests or activity of a legal entity; f) production in any form, import, export, storage, offer for sale or sale of merchandise or services with false indications ${ }^{6}$ on invention patents, patents for plant types, trademarks, geographical indications, drawings or industrial models, topographies of semiconductor products, other types of intellectual property, such as the outer image of the company, showcase design or clothing design for staff, advertising means and similar, origin and characteristics of merchandise, as well as with regard to the name of the producer or dealer, in order to mislead the other dealers and beneficiaries.

- the crimes stipulated by Law no. 297/2004 on the capital market ${ }^{7}$ are those stipulated under art. 279 of this regulation, consisting of: a) intentional presentation by the administrator, manager or executive manager of the company to shareholders of inaccurate financial statements or false information related to the company economic circumstances; b) perpetration of market manipulation, market abuse or inappropriate use of privileged information ${ }^{8}$, stipulated under art. 245-248 of Law no. 297/2004; c)

\footnotetext{
${ }^{4}$ Published in the Official Journal of Romania, Part I, no. 24 dated 30 January 1991, as amended and supplemented.

${ }^{5}$ It can be found that the lawmaker chose to limit to scenarios under art. 175, para. (1) of the Criminal Code, excluding those under art. 175, para. (2) of the Criminal Code.

${ }^{6}$ False indications on the origin of goods, in the meaning under para. 1 letter $\mathrm{f}$ ), mean any indications likely to induce the idea that the goods have been manufactured in a particular locality, territory or State. False indication regarding the origin of goods does not include the name of products with a name that became generic and only indicates its nature, apart from the situation when the name is accompanied by a mention that could lead to the belief that those goods have that origin.

7 Published in the Official Journal of Romania, Part I, no. 571 dated 29 July 2004, as amended and supplemented.

8 According to art. 244, para. (1) of Law no. 297/2004, privileged information means information of precise nature which was not made public, which refers directly or indirectly to one or more issuers or one or more
} 
purposeful access by unauthorized persons of electronic systems for transaction, storage or settlement;

- crimes stipulated under Law no. 241/2005 for the prevention and countering of tax evasion, if the respective case, regardless of the number of concurring crimes, the generated material damage exceeds the Romanian currency equivalent of EUR 500,000.00;

- crimes stipulated by Law no. 86/2006 on the Romanian Customs Duty Code, namely contraband, aggravated contraband, use of false documents for Customs authorities;

- the crime stipulated under art. 155 of Law no. 95/2006 on the reformation of the health sector" ${ }^{9}$, consisting of: "harvesting or transplant of organs, tissue or cells of human origin from live donors without a consent given according to the Law".

b. crimes that involve DIOCT's authority, regardless of them being committed or not within the organized crime group:

- crimes stipulated under art. 210 Criminal Code (trafficking of persons), 211 Criminal Code (trafficking of underage persons), as well as attempted trafficking, art. 303 Criminal Code (disclosure of Secret of State information), including the instance of particularly severe and material consequences, art. 325 Criminal Code (computer fraud), including the scenario where it is committed in relation with the authority of a foreign State, art. 360 Criminal Code (illegal access to a computer system), art. 361 Criminal Code (illegal interception/tapping of a transmission of computer data), art. 362 Criminal Code (alteration of integrity for computer data) art. 363 Criminal Code (disturbance of operation of computer systems), art. 364 Criminal Code (unauthorized transfer of computer data), art. 365 Criminal Code (illegal operations with computer devices or programs), as well as the attempted crimes specified above, art. 374 Criminal Code (child pornography), art. 394412 Criminal Code (crimes against national security);

- crimes specified under Law no. 51/1991 on the national security of Romania;

- crimes stipulated under Law no. 111/1996 on the safe performance, regulation, authorization and control of nuclear activities;

- crimes specified under Law no. 143/2000 on the prevention and countering of trafficking and illicit consumption of drugs;

- crimes specified under Law no. 535/2004 on the prevention and countering of terrorism;

- crimes specified under the Government Emergency Ordinance no. 121/2006 on the legal conditions of drug precursors ${ }^{10}$;

- crimes specified under Law no. 194/2011 on countering operations with products susceptible of having psychoactive effects, other than those stipulated in the regulations in force.

c. the crime stipulated under article 367 of the Criminal Code, if the purposes of the criminal group include any of the crimes specified above;

financial instruments and which, if they were made public, may have a significant impact on the price of such financial instruments or the price of derivatives they are related to.

${ }^{9}$ Published in the Official Journal of Romania, Part I, no. 372 dated 28 April 2006, as amended and supplemented.

${ }^{10}$ Approved with modifications by Law no. 186/2007, as amended. 


\section{B. Micu}

d. the crime of money laundering stipulated under Law no. 656/2002 for the prevention and sanctioning of money laundering, as well as for the establishment of measures to prevent and counter the financing of terrorism, republished, as amended, if the money, goods and values subject to money laundering are generated by the perpetration of crimes assigned to the authority of the Directorate for Investigating Organized Crime and Terrorism;

e. crimes which are related, according to art. 43 Criminal Procedure Code, to those stipulated under letters a)-d). These are the situations where it is justified to merge two or more cases. Concretely, DIOCT's authority shall cover the investigation of crimes committed by the same person who perpetrated a crime of those specified above, even if judging by their nature they would not fit this area of competence/authority. The same is the solution when two or more crimes are related and it is necessary to merge the cases for the proper serving of justice, even if only one of the crimes falls under DIOCT's authority.

\section{Some incidents related to the competence of specialized judicial entities}

The indications of the special law as representing the material competence with regard to DIOCT's criminal investigation represent the rule, and particular exceptions are possible from this rule.

Therefore, it is possible that one of the crimes under DIOCT's authority is committed in criminal participation conditions by persons who are in a military position and by persons without such position. Under such circumstances competence and authority must be established, because art. 54, para. (3) of the Criminal Procedure Code indicates that "criminal prosecution in case of crimes perpetrated by members of the military must be performed by the military prosecutor". The quoted text considers the scenario where all participants in a crime are members of the military. However, if the criminal prosecution case includes at least one defendant which is not a member of the military, consideration must be given to dispositions under art. 63, para. (1) Criminal Procedure Code, related to art. 44, para. (4) and (5) Criminal Procedure Code, the prosecution authority belonging, under such circumstances, either to the civil criminal prosecution entity with equal ranking to the military prosecution entity, or to the civil criminal prosecution entity with equivalent ranking to the military prosecution entity (if the military prosecution entity has a superior ranking than the civil one).

In other concrete circumstances, there may be a positive conflict of authority and competence between DIOCT and the National Anticorruption Directorate (hereinafter referred to as NAD), considering the nature of the crime and the damages generated by the perpetration of such crime. Therefore, we can make reference to a scenario where an embezzlement of public tender occurs (art. 246 Criminal Code) in the circumstances of an organized criminal group which generates a damage of EUR 1,200,000.00. Under such circumstances, the generated damage exceeds the threshold of EUR 500,000.00 specified under art. 12, para. 1, letter a, section ii) of Law no. 508/2004, coming under the authority of DIOCT, but is also in excess of the EUR 1,000,000 specified under art. 13, para. (3) of Ordinance no. 43/2002, and it can come under the authority of the NAD. We believe that under such circumstances the competence and authority to perform the criminal prosecution shall be with the judicial entity notified first. The solution is indicated by the provisions of art. 63 related with art. 44, para. (1) of the Criminal Procedure Code. Art. 63 states expressly that, among others, provisions of art. 44, para. (1) of the Criminal Procedure Code also apply correspondingly during the criminal prosecution, and the referenced text in case of merger, if, in comparison with various perpetrators or different crimes, the competence belongs, according to the law, to multiple courts of equal ranking, the competence to judge all crimes and all perpetrators belongs to the court notified first.

In the extent that a crime which, according to its nature, belongs to the authority of DIOCT is perpetrated by a person in a position that involved higher competence, on the grounds of art. 63 related with art. 44, para. 1, the final thesis in the Criminal Procedure Code: 
"if, considering the position of persons, competence belongs to courts of various rankings, the competence and authority to judge all merged cases belongs to the court of higher ranking", and this disposition is also applicable with regard to criminal prosecution entities.

\section{Conclusions}

Even in practical situations there are cases of positive conflict of competence between the specialized prosecuting authorities, it is more important that no author of a serious crime to remain unpunished than to keep rigid limits of material competences. In the same time, is capital in order to respect international standards in human rights protection to create efficient mechanisms to avoid bis in idem cases and to respect the legality ${ }^{11}$.

\section{Bibliography}

I. Neagu, M. Damaschin, Tratat de procedură penală, Partea generală, „Universul Juridic” Publishing House, Bucureşti, 2014;

C. Nedelcu, Criminalistică , „Hamangiu” Publishing House, Bucureşti, 2014;

Mirela Gorunescu, I.A. Barbu, Mihaela Rotaru, Drept penal, Partea generală, "Universul Juridic” Publishing House, Bucureşti, 2014.

\footnotetext{
${ }^{11}$ C. Nedelcu, Criminalistică, Hamangiu PH, Bucureşti, 2014, p. 15.
} 